\title{
Voluntary Firefighter Crews at the Mantiqueira Conservation Units Mosaic
}

\author{
Virgilio Dias Ferraz¹, Mario Kozlowski Pitombeira ${ }^{2}$, Selma Cristina Ribeiro ${ }^{1}$, Albano Lameiras \\ da Paz, Levy Cardoso ${ }^{4}$, Raquel Filippo Fernandes Hellich ${ }^{5}$, Marcelo Souza Motta ${ }^{2}$
}

\begin{abstract}
${ }^{1}$ Instituto Chico Mendes de Conservação da Biodiversidade - ICMBio / Área de Proteção Ambiental da Serra da Mantiqueira, Itamonte, MG, Brasil. E-mails: virgilio.ferraz@icmbio.gov.br; selma.cristina@icmbio.gov.br

${ }^{2}$ Instituto Chico Mendes de Conservação da Biodiversidade - ICMBio / Parque Nacional do Itatiaia, Itatiaia, RJ, Brasil. E-mails: mario.pitombeira@icmbio.gov.br; marcelo.motta@icmbio.gov.br

3 Brigada Voluntária do Alto Rio Preto, Resende, RJ, Itatiaia, RJ, Brasil. E-mail: albanopaz2014@gmail.com

4 Grupo Voluntário de Busca e Salvamento Anjos da Montanha, Itatiaia, RJ, Brasil. E-mail: levy.ecologico@hotmail.com

${ }^{5}$ Brigada Voluntária da Serra dos Garcias, Aiuruoca, MG, Brasil. E-mail: raquel.hellich@gmail.com
\end{abstract}

\begin{abstract}
The Mantiqueira's mountain range, known as Serra da Mantiqueira, is considered by the scientific community as one of the irreplaceable areas for the biodiversity conservation (LE SAOUT et al, 2013). This mountain range is partially protected by two categories of protected area: "integral protection" and "sustainable use", created and managed by different governmental spheres, which compose the Mantiqueira Mosaic (Brazilian Ministry of the Environment - MMA Ordinance No. 351/2006) that currently has 17 Public Conservation Units (CUs) and 56 Private Natural Heritage Reserves (PNHRs). Complementary to the government agencies, civil society has always played an important role in the regional conservation, both by its historical engagement in movements to create new CUs, as well as by participating in those management councils. To train, equip and then, form voluntary firefighter crews is another example of the local society's engagement in the protection of Serra da Mantiqueira. It is an important tool to promote participatory management and increase social mobilization. In addition, the whole process mainly aimed to empower the owners and employees of the PNHRs, mountain guides, rural labor unions, city halls, farmers and organized civil society. At the end of the training course, voluntary firefighter crews are equipped with tools and personal protection equipment. In result, this proposal provides the society with trained and equipped firefighters squad in order to carry out the first attack, in case of wildfire. This paper presents data about the number of volunteers trained, in recent years, by the Chico Mendes Biodiversity Institute (ICMBio), through the volunteer program ruled by the Serra da Mantiqueira Environment Protected Area and Itatiaia National Park. The contingent of volunteers that have been trained or updated and equipped by ICMBio in the last 3 years, add up 89 new members, who are distributed in the municipalities of Aiuruoca, Cruzeiro, Delfim Moreira, Itamonte, Itatiaia, Marmelópolis and Resende, among the states of Minas Gerais, Rio de Janeiro and São Paulo, covering the Grande and Paraíba do Sul upper watershed. Despite the institutional effort, there are two main limiting factors to increase the number of volunteer firefighters: First is the difficulty to provide personal protective and combat equipment to volunteers. Second is the obligation to update personal and institutional documentation. It is noteworthy that the volunteers firefighters work in various CUs within the territory of Mantiqueira Mosaic.
\end{abstract}

Keywords: Serra da Mantiqueira; Conservation Units Mosaic; Volunteer Program; Forest Fires. 